\title{
Is Listening Comprehension a Comprehensible Input for L2 Vocabulary Acquisition?
}

\author{
Saud Mushait ${ }^{1} \&$ Mohammed Ali Mohsen ${ }^{1}$ \\ ${ }^{1}$ Faculty of Languages, Najran University, Saudi Arabia \\ Correspondence: Mohammed Ali Mohsen, Faculty of Languages, Najran University, Saudi Arabia. E-mail: \\ mmohsen1976@gmail.com
}

Received: August 1, 2019 Accepted: August 24, 2019 Online Published: October 13, 2019

doi:10.5539/ijel.v9n6p77 URL: https://doi.org/10.5539/ijel.v9n6p77

\begin{abstract}
Vocabulary learning has received considerable attention from reading comprehension input in second language acquisition research. However, a little is known about vocabulary gains from listening comprehension input. This paper aims to review L2 vocabulary gains from listening comprehension input in comparison to reading comprehension and reading while listening comprehension activities. We search for the terms "vocabulary learning", "vocabulary acquisition", and "listening comprehension" in several international databases to elicit target studies. The target studies have been reviewed in terms of focus, methodology employed, L2 environment, type of participants, and findings. Results of the review found that vocabulary acquisition from listening comprehension input was significant - though less than reading input — for long run and could be stored in long term memory. Therefore, it could be retrieved more easily than vocabulary from reading comprehension input. Recommendations and suggestions for future research have been given at the end of the article.
\end{abstract}

Keywords: listening comprehension, vocabulary acquisition, input, second language

\section{Introduction}

Vocabulary acquisition is a key for mastering the language skills and plays a pivotal role in successful communication. The importance of vocabulary learning is summed up by Wilkins (1972, p. 111) "without grammar very little can be conveyed, without vocabulary nothing can be conveyed". Read (2000, p. 1) refers to words as the "basic building blocks of a language, the units of meaning from which larger structures such as sentences, paragraphs and whole texts are formed". There is no doubt that L2 vocabulary plays an important role in learning a foreign or second language. Meara (1996) argues that "lexical competence is at the heart of communicative competence" (p. 35). Learning a foreign or a second language at intermediate and advanced levels of proficiency involves the acquisition of many thousands of words. Teachers and learners alike would like to know in which ways instructional programs might foster the acquisition of so many words (Laufer \& Hulstijn, 2001). One of the main principles in English as a foreign language (EFL) is that the number of words will delimit the understanding of a second language. Different researchers (Laufer, 1997; Nation, 2000) spoke about the importance of acquiring a minimum of vocabulary so that student can understand a text. Laufer (1997, p. 20) asserts that "no text comprehension is possible, either in one's native language or in a foreign language without understanding the text's vocabulary".

Second language acquisition (SLA) theory seeks for effective inputs through which learners can involve to acquire a foreign/second language. Krashen (1982) introduced "Input Hypothesis" which assumed that L2 acquisition should be enhanced through incidental learning of a new language from contextually rich verbal input. As the quality of learning language outcomes solely rely on the language input students are exposing to. Therefore, practitioners and language teachers have been looking for a "comprehensible input" which goes beyond the students' proficiency level. Previously, input about five decades back was restricted to text material presented in printed forms like papers, books, magazines, and newsletters or to audio material given by a tape-recording machine. In that regard, students were asked to read or listen for comprehension and extracted new words that were learned incidentally through a single input, i.e. reading or listening contexts. Currently, input was broadened to cover not only textual material but other modes like aural material and audio-visual material where learners can acquire learning from exposure to listening input.

In this paper we aim to review previous studies that tackle the issue of vocabulary acquisition from different 
perspectives; (1) studies that tested vocabulary acquisition from pure listening, (2) studies that compared vocabulary acquisition from listening versus reading comprehension activities, and (3) studies compared between vocabulary acquired from listening, reading, reading while listening.

\section{Literature Review}

The famous model for accounting the listening comprehension process is the cognitive psychology. In its perspective, Schemata are the guiding structures in the comprehension process. The schema is described by Rumelhart (1980) as "a data structure for representing the generic concepts stored in a memory. It can be used to represent our knowledge about all concepts: those underlying objects, situations, events, sequences of events, actions and sequences of actions" (p. 34). What is meant by the term "schema" as proposed the cognitive comprehension theory, is that the strategy made by learners to make sense of the targeted text. The learners integrate both linguistic and situational cues to the predictions he/she has about the new input to evoke schemata. This schema will help learners comprehend the input he or she received.

Second language vocabulary acquisition has become a hotspot issue of research and topic of discussion for instructors, curriculum designers, practitioners, and other pedagogues involved in second language acquisition due to the influence vocabulary has on successful communication (Coady \& Huckin, 1997). One of the major problems facing second language learners is that they understand very little vocabulary at the beginning stages; often this is a result of insufficient vocabulary knowledge (Nikolova, 2004). Foreign language vocabulary is viewed as a primary factor in successful communication and, to a great extent, in high level reading ability. Krashen (1982) points out that "When students travel, they don't carry grammar books, they carry dictionaries." (Krashen, 1982, p. iii). Stæhr (2009) argues that there is a strong relationship between listening comprehension and vocabulary acquisition. A great deal of vocabulary knowledge contributes to successful listening comprehension whereas the listening input can provide a rich context for learning new words.

According to Zimmerman (1997), vocabulary is typically neglected in foreign or second language instruction. She inferred that the most second language learners have traditionally been taught by methods that gave minimal attention to vocabulary. One of the major concerns for researchers is the need for developing effective pedagogical methods for the teaching of second language vocabulary. Traditional instructional methods for vocabulary learning include word-lists, checking dictionary, puzzles, materials made by teachers, and group discussion. Yet, developing effective pedagogical methods for vocabulary acquisition continues to demand attention and exploration (Iheanacho, 1997).

\subsection{Breadth and Depth of Vocabulary Learning}

Some researchers (Qian; 1999; Read, 1993; Wesche \& Paribakht, 1996; Stæhr, 2009; Ataş, 2018) recognized the distinction between breadth and depth of vocabulary. Vocabulary breadth refers to the size or the number of words known by the learners of a language. Mear (1996) highlighted the importance of vocabulary size in playing a leading role in the learner's lexical competence. He also argued that having a large vocabulary size puts language learners at an advantage in terms of language proficiency. In other words, learners with adequate vocabulary size are more likely to be more proficient language users than those with limited vocabulary.

In this regard, Stæhr (2009) examined the relative contribution of vocabulary depth (the quality of lexical knowledge) and breadth (size) to LC. He also investigated how much vocabulary size is required for adequate listening comprehension. 115 male and female advanced Danish EFL first year students in the Copenhagen Business School took part in the data collection. The author used the VLT (Schmitt, Schmitt, \& Clapham, 2001) (a vocabulary size test) and the Word Association Test (Read, 1993, 1998) (the depth test) were used to assess the participants' vocabulary knowledge, and a third test (the advanced CPE) to measure the subjects' LC. All the three measures were administered in one session and lasted for about 120 minutes .Stæhr performed correlation analysis and multiple regression analysis (stepwise method). The result of correlation analysis shows a relatively high correlation between the vocabulary size and depth, on the one hand, and listening comprehension on the other. The vocabulary size shows a correlation of .70, whereas the word association test (vocabulary depth) produces a correlation of .65 . Both results are significant $(\mathrm{p}<.01)$. The result also shows a high correlation between the two vocabulary tests $(\mathrm{r}=.80, \mathrm{p}<.01)$.

The result of multiple regression analysis demonstrates also a significant result between the variables in question. The vocabulary size alone explains $49 \%$ of the variance in LC $(\mathrm{F}=106.45, \mathrm{p}<.01)$. When the scores of the vocabulary depth were added to the regression equation a further $2 \%$ were added $(\mathrm{F}=6.13, \mathrm{p}<.05)$. In other words, both vocabulary variables explained $51 \%$ of the variance in LC $(p<.01)$. This result as Stæhr puts it "suggests the vocabulary size [vocabulary breadth] is the basic component of vocabulary knowledge in listening comprehension and that depth of vocabulary knowledge does not play a separate role" (p. 592). 


\subsection{Models of Vocabulary Learning}

Two modes of information processing: bottom-up processing and top-down processing have been resulted from the schema principle. Bottom-up processing the former acknowledges that listening occurs from decoding the smallest unit (phonemes) to the largest one (meaningful text). The later (top-down) processing, in which the listener constructs the whole meaning of the texts and builds previous information in his/her mental lexicon to comprehend the target input.

The above two models intersect to develop a third model i.e. an interactive model. The interactive processing model overcomes the disadvantages of bottom-up processing and top-down processing to augment the comprehension. The proponents of this model argue that listening comprehension is neither top-down nor bottom-up processing, but an interactive, interpretive process where listeners use both prior knowledge and linguistic knowledge in understanding messages (Vandergrift, 2007). The degree to which listeners use one those models will depend on their knowledge of the language, familiarity with the topic or the purpose for listening.

In the present age, modern technology has made listening input more accessible than before due to the spread of videos synchronized with subtitles or captions which helps to ease listening comprehension and makes learners more engaged in listening input. Therefore, listening input has become comprehensible input for vocabulary learning. Previous studies made an attempt to how and to what extent vocabulary acquisition could be made from exposure to listening material.

\section{Methodology}

In order to compile studies for vocabulary acquisition from listening input, we searched in international databases (Web of Science, Scopus, Educational Resources Information Center (ERIC), using keywords search; vocabulary learning, vocabulary acquisition, vocabulary listening, vocabulary reading. A significant number of studies have been collected from the search which meet the criteria of this study; (1) the target language is English, (2) the focus is vocabulary acquisition, (3) studies should be empirical. We exclude vocabulary acquisition from reading comprehension input or studies that categorized as systematic review, meta-analysis or conceptual papers. We summarize the selected studies from the search as per the following sub-categories.

\section{Results and Discussions}

\subsection{Vocabulary from Listening Input}

Only few studies have been conducted in regards to vocabulary acquisition from listening input. A possible explanation for that is the area of listening has not been sufficiently researched and was neglected for decades (Vandergrift, 2007). 
Table 1. Vocabulary acquisition studies from listening

\begin{tabular}{|c|c|c|c|c|}
\hline Study & Variables investigated & Participants & Tests administered & Main findings \\
\hline $\begin{array}{l}\text { van Zeeland and } \\
\text { Schmitt (2013) }\end{array}$ & $\begin{array}{l}\text { Vocabulary learning and } \\
\text { retention through } \\
\text { listening }\end{array}$ & $\begin{array}{l}\text { High-intermediate to } \\
\text { advanced learners }\end{array}$ & $\begin{array}{l}\text { Form recognition, } \\
\text { grammar recognition, } \\
\text { and writing down the } \\
\text { meaning (productive } \\
\text { test) }\end{array}$ & $\begin{array}{l}\text { Learners gained } 29 \% \text { of the target } \\
\text { words immediately after listening } \\
\text { and retained } 19 \% \text { of the words two } \\
\text { weeks later }\end{array}$ \\
\hline Maneshi (2017) & $\begin{array}{l}\text { IVA through listening to } \\
\text { songs }\end{array}$ & Fifth-grade students & Multiple-choice tests & $\begin{array}{l}\text { Positive contribution of listening to } \\
\text { songs on vocabulary acquisition and } \\
\text { increase in vocabulary gains with } \\
\text { repeated listening }\end{array}$ \\
\hline $\begin{array}{l}\text { Albaladejo, } \\
\text { Coyle and de } \\
\text { Larios (2018) }\end{array}$ & $\begin{array}{l}\text { Vocabulary growth from } \\
\text { story narration versus } \\
\text { songs and combination of } \\
\text { the two }\end{array}$ & 2-3years children & Recall tests & $\begin{array}{l}\text { Story strategy was significant for } \\
\text { vocabulary growth. }\end{array}$ \\
\hline $\begin{array}{l}\text { Coyle and } \\
\text { Gómez Gracia } \\
(2014)\end{array}$ & $\begin{array}{l}\text { Spanish L2 vocabulary } \\
\text { acquisition }\end{array}$ & for 5 years old & Picture test & $\begin{array}{l}\text { involvement in songs would lead to } \\
\text { acquire receptive vocabulary but } \\
\text { insufficient to learn productive } \\
\text { vocabulary }\end{array}$ \\
\hline $\begin{array}{l}\text { Ellis and Le } \\
\text { (2016) }\end{array}$ & $\begin{array}{l}\text { L2 vocabulary acquisition } \\
\text { from Inference and text } \\
\text { repetition }\end{array}$ & University students & $\begin{array}{l}\text { form test, reception } \\
\text { test, and recall test }\end{array}$ & $\begin{array}{l}\text { text repetition impacted vocabulary } \\
\text { acquisition while inference-training } \\
\text { showed no effect }\end{array}$ \\
\hline $\begin{array}{l}\text { Hazrat and } \\
\text { Hessamy (2013) }\end{array}$ & $\begin{array}{l}\text { effect of vocabulary } \\
\text { preparation on listening } \\
\text { comprehension, } \\
\text { vocabulary learning, and } \\
\text { vocabulary learning } \\
\text { strategy use. }\end{array}$ & $\begin{array}{l}42 \text { female adult } \\
\text { Iranian EFL } \\
\text { intermediate level } \\
\text { students }\end{array}$ & $\begin{array}{l}\text { two active and two } \\
\text { passive vocabulary } \\
\text { test scores and two } \\
\text { listening test scores } \\
\text { for words treated } \\
\text { through oral and } \\
\text { written output } \\
\text { separately }\end{array}$ & $\begin{array}{l}\text { learning vocabulary through oral } \\
\text { pushed output was more effective in } \\
\text { promoting listening comprehension } \\
\text { than learning vocabulary through } \\
\text { written pushed output. }\end{array}$ \\
\hline Ataş (2018) & $\begin{array}{l}\text { the relationship between } \\
\text { vocabulary knowledge } \\
\text { (VK) in the L2 and } \\
\text { listening comprehension. }\end{array}$ & $\begin{array}{l}33 \text { Turkish advanced } \\
\text { learners of EFL at a } \\
\text { state university, }\end{array}$ & $\begin{array}{l}\text { a vocabulary test and } \\
\text { a listening } \\
\text { comprehending test. }\end{array}$ & $\begin{array}{l}\text { There was a significant correlation } \\
\text { between the total scores of the } \\
\text { vocabulary test and the scores of the } \\
\text { listening comprehension test. }\end{array}$ \\
\hline $\begin{array}{l}\text { Migdadi, } \\
\text { Yunus, and } \\
\text { Daradkeh } \\
\text { (2019) }\end{array}$ & $\begin{array}{l}\text { potential effect of } \\
\text { vocabulary knowledge } \\
\text { including both breadth } \\
\text { and depth on listening } \\
\text { comprehension. }\end{array}$ & $\begin{array}{l}40 \text { preparatory year } \\
\text { university Saudi } \\
\text { students }\end{array}$ & $\begin{array}{l}\text { Vocabulary test and } \\
\text { listening } \\
\text { comprehension test } \\
\text { prepared by the } \\
\text { researchers }\end{array}$ & $\begin{array}{l}\text { There was a significant correlation } \\
\text { between the vocabulary depth } \\
\text { listening comprehension. }\end{array}$ \\
\hline $\begin{array}{l}\text { Musa and } \\
\text { Fojkar (2019) }\end{array}$ & $\begin{array}{l}\text { relationship between the } \\
\text { three following variables: } \\
\text { 1) out-of-classroom } \\
\text { exposure to English; 2) } \\
\text { levels of English listening } \\
\text { skills; and 3) vocabulary } \\
\text { proficiency }\end{array}$ & $\begin{array}{l}133 \text { primary school } \\
\text { learners on their } 9^{\text {th }} \\
\text { grade. }\end{array}$ & $\begin{array}{l}\text { listening } \\
\text { comprehension and } \\
\text { vocabulary test, and a } \\
\text { questionnaire }\end{array}$ & $\begin{array}{l}\text { a significant correlation was found } \\
\text { between listening comprehension } \\
\text { and vocabulary performance for } \\
\text { both males and females. } \\
\text { Furthermore, a significant } \\
\text { relationship was found between the } \\
\text { out-of-classroom exposure to } \\
\text { English through both audio-visual } \\
\text { and audio forms and the learners' } \\
\text { listening skills and vocabulary } \\
\text { performances. In contrast, no } \\
\text { significant relationship was found } \\
\text { between using video games in } \\
\text { English, on the one hand, and } \\
\text { pupils' listening comprehension and } \\
\text { vocabulary on the other. }\end{array}$ \\
\hline
\end{tabular}

\subsection{Vocabulary from Reading Versus Listening}

There was great interest among researchers to track and compare how vocabulary acquisition took place in both listening and reading comprehension inputs and to what extent vocabulary learning would last for long term memory. Table 2 summarizes the most prominent studies in the field. 
Table 2. Vocabulary acquisition from reading versus listening

\begin{tabular}{|c|c|c|c|c|}
\hline Study & Variables investigated & Participants & Tests administered & Main findings \\
\hline Vidal (2011) & $\begin{array}{l}\text { Effect of reading and } \\
\text { listening on IVA and } \\
\text { retention }\end{array}$ & $\begin{array}{l}\text { University learners at } \\
\text { four different levels of } \\
\text { language proficiency }\end{array}$ & $\begin{array}{l}\text { Recognition test } \\
\text { Production tests } \\
\text { (meaning } \\
\text { explanation, word } \\
\text { translation and word } \\
\text { usage) }\end{array}$ & $\begin{array}{l}\text { Immediate gains of listeners were } \\
\text { extremely low and their gain } \\
\text { retention was weaker than that of } \\
\text { readers of the same proficiency level, } \\
\text { except for advanced learners }\end{array}$ \\
\hline Hatami (2017) & $\begin{array}{l}\text { Effect of L2 reading and } \\
\text { listening on IVA and } \\
\text { retention and the } \\
\text { relationship between } \\
\text { frequency of word } \\
\text { occurrence and IVA } \\
\text { through reading and } \\
\text { listening }\end{array}$ & $\begin{array}{l}\text { Pre-intermediate-level } \\
\text { English language } \\
\text { learners }\end{array}$ & $\begin{array}{l}\text { Five recognition tests } \\
\text { and one recall test }\end{array}$ & $\begin{array}{l}\text { Readers scored higher than listeners } \\
\text { in all dimensions of word knowledge } \\
\text { and word retention }\end{array}$ \\
\hline $\begin{array}{l}\text { Suggate, } \\
\text { Lenhard, } \\
\text { Neudecker, and } \\
\text { Schneider (2013) }\end{array}$ & $\begin{array}{l}\text { Effects of reading, } \\
\text { telling, and sharing a } \\
\text { story on vocabulary } \\
\text { acquisition }\end{array}$ & Fourth-grade students & Word translation test & $\begin{array}{l}\text { The least number of words was } \\
\text { learned when reading stories } \\
\text { independently, and the most number } \\
\text { of words was learned from the free } \\
\text { story telling condition }\end{array}$ \\
\hline $\begin{array}{l}\text { Xiaoning and } \\
\text { Feng (2017) }\end{array}$ & $\begin{array}{l}\text { Effect of word frequency } \\
\text { in reading and listening } \\
\text { on IVA and retention }\end{array}$ & $\begin{array}{l}\text { University learners of } \\
\text { English language }\end{array}$ & $\begin{array}{l}\text { Passive recall of form } \\
\text { test Receptive } \\
\text { recognition of form } \\
\text { Passive recall in } \\
\text { multiple-choice test } \\
\text { of meaning }\end{array}$ & $\begin{array}{l}\text { Both modes enhanced vocabulary } \\
\text { acquisition, but more word } \\
\text { knowledge was gained from reading }\end{array}$ \\
\hline $\begin{array}{l}\text { Mohsen and } \\
\text { Medawis (2019) }\end{array}$ & $\begin{array}{l}\text { Vocabulary gains } \\
\text { (recognition }+ \\
\text { production) from reading } \\
\text { versus listening input }\end{array}$ & EFL university students & $\begin{array}{l}\text { multiple choice } \\
\text { questions plus cloze } \\
\text { test }\end{array}$ & $\begin{array}{l}\text { Performance of listeners was } \\
\text { significantly lower than that of } \\
\text { readers after the first session, almost } \\
\text { the same after the second session, } \\
\text { and significantly higher after the } \\
\text { third listening session }\end{array}$ \\
\hline
\end{tabular}

\subsection{Vocabulary from Reading while Listening}

The advancement of the modern technology has visualized auditory materials and synchronized videos with captions (i.e., a text provided in the language of the video) or subtitles (text provided in the audience target language) (Mohsen, 2016; Mohsen \& Mahdi, 2019). Therefore, it is difficult to classify video captioning provided with multimedia presentations as reading or listening input. The best term that can best describe it is reading while listening (Tragant Mestres, Llanes Baró, \& Garriga, 2018). Table 3 summarizes the studies that dealt with vocabulary from reading while listening.

Table 3. Vocabulary acquisition studies from reading while listening

\begin{tabular}{|c|c|c|c|c|}
\hline Study & Variables investigated & Participants & Tests administered & Main findings \\
\hline $\begin{array}{l}\text { Tragant Mestres, } \\
\text { Llanes Baró and } \\
\text { Garriga (2018) }\end{array}$ & $\begin{array}{l}\text { Vocabulary acquisition from } \\
\text { reading-while-listening, } \\
\text { reading only, and control } \\
\text { group }\end{array}$ & $\begin{array}{l}\text { Spanish students } \\
\text { studying } \\
\text { English as a } \\
\text { third language }\end{array}$ & $\begin{array}{l}\text { dictation and } \\
\text { vocabulary test }\end{array}$ & $\begin{array}{l}\text { The two treatments groups outscored their } \\
\text { counterparts in vocabulary test but } \\
\text { did not show superior scores in reading or } \\
\text { listening comprehension or reading fluency. }\end{array}$ \\
\hline $\begin{array}{l}\text { Valentini, } \\
\text { Ricketts, Py and } \\
\text { Houston-Price } \\
(2018)\end{array}$ & $\begin{array}{l}\text { Words' orthography, } \\
\text { phonology, and semantics } \\
\text { information in a story context }\end{array}$ & $\begin{array}{l}71 \text { English } \\
\text { children }(7-9 \\
\text { years old) }\end{array}$ & $\begin{array}{l}\text { Picture vocabulary } \\
\text { test, phonological test, } \\
\text { orthographic, and } \\
\text { semantic test }\end{array}$ & $\begin{array}{l}\text { Children obtained greater phonological } \\
\text { feature when are not exposed to phonology } \\
\text { mode while words orthography were easily } \\
\text { acquired for children when exposed to the } \\
\text { same mode. }\end{array}$ \\
\hline Teng (2018) & $\begin{array}{l}\text { Vocabulary learning from } \\
\text { reading versus reading while } \\
\text { listening }\end{array}$ & $\begin{array}{l}\text { Chinese EFL } \\
\text { learners }\end{array}$ & $\begin{array}{l}\text { four domains; form } \\
\text { recognition, grammar } \\
\text { recognition, meaning } \\
\text { recall, and collocation } \\
\text { recognition. }\end{array}$ & $\begin{array}{l}\text { Reading-while-listening condition was more } \\
\text { effective for incidental vocabulary } \\
\text { acquisition than the reading-only condition } \\
\text { for both word exposure frequency and } \\
\text { elaborate word processing. }\end{array}$ \\
\hline
\end{tabular}




\subsection{Pedagogical Implications}

Several pedagogical implications are raised for language instructors to focus more on exposing learners to authentic input where learners can be accustomed to different accents of the target language. Instructors should made use of the modern technology to engage learners in more audio and videos where different varieties of accents are provided. Leaners need to get familiar with native speakers accent to understand how vocabulary is pronounced and then how these words would be appeared in written form. Learners can map the phonological forms of these words with their orthographical form in order to ensure L2 learners mastery of words. As for the implications of this review, EFL instructors should exploit the affordances of the comprehensible listening comprehension input to help learners augment their vocabulary acquisition and should leverage the potential of multimedia help option which visualize the listening materials and give options for learners to see words orthography in synchrony with words pronunciation.

\subsection{Limitations and Future Studies}

This review has mainly focused on tackling studies that examined L2 vocabulary acquisition from listening input or acquisition in comparison to reading comprehension input. Future studies should review large scale of studies in the literature and can include studies from other databases. The authors would recommend conducting quantitative data by carrying out meta-analyzed studies where effects size could be calculated to see exactly how the magnitude of effects of listening comprehension on L2 vocabulary acquisition. The findings summarized in this study are subjective because the nature of systematic reviews cannot do statistical analysis among the target studies. Therefore, doing meta-analysis studies are called for future research.

\section{Conclusion}

The findings of the reviewed studies in this paper indicate that listening comprehension input is one of the richest comprehensible inputs that could foster L2 vocabulary acquisition. Though, it is not sufficiently researched when it is compared to reading comprehension input, it is a crucial input that could help learners acquire L2 vocabulary acquisition both incidentally and intentionally. Previous studies varied in the data collection tools, different types of measurements, varied contexts and they unanimously agree that learners did learn significantly from listening comprehension input. The advent of modern technology helps to convert listening from audio mode into audio-visual mode accompanied with text, annotations, scripts and dictionary check. The results of the above-mentioned studies demonstrate that vocabulary acquisition could be learned from combined input'; reading while listening, as this mode can combine two modes and help learners to store vocabulary in long-term memory.

\section{References}

Albaladejo, S., Coyle, Y., \& de Larios, J. R. (2018). Songs, stories, and vocabulary acquisition in preschool learners of English as a foreign language. System, 76, 116-128. https://doi.org/10.1016/j.system.2018.05.002

Atas, U. (2018). The role of receptive vocabulary knowledge in advanced EFL listening comprehension. The Electronic Journal for English as a Second Language, 21(4), 1-12.

Coady, J., \& Huckin, T. (1997). Second Language Vocabulary Acquisition. Cambridge: Cambridge University Press. https://doi.org/10.1017/CBO9781139524643

Coyle, Y., \& Gomez, G. R. (2014). Using songs to enhance L2 vocabulary acquisition in preschool children. ELT Journal, 68(3), 276-285. https://doi.org/10.1093/elt/ccu015

Ellis, R., \& Le, C. (2016). The effects of inference-training and text repetition on Chinese learners' incidental vocabulary acquisition while listening. Chinese Journal of Applied Linguistics, 39(2), 137-152. https://doi.org/10.1515/cjal-2016-0009

Hatami, S. (2017). The differential impact of reading and listening on L2 incidental acquisition of different dimensions of word knowledge. Reading in a Foreign Language, 29(1), 61-85.

Hazrat, M., \& Hessamy, G. (2013). The impact of two types of vocabulary preparation on listening comprehension, vocabulary learning, and vocabulary learning strategy use. Theory and Practice in Language Studies, 3(8) 1453-1461. https://doi.org/10.4304/tpls.3.8.1453-1461

Iheanacho, C. C. (1997). Effects of two multimedia computer-assisted language learning programs on vocabulary acquisition of intermediate level ESL students. Unpublished doctoral dissertation. Virginia Polytechnic Institute and State University. Blacksburg, VA. 
Krashen, S. (1982). Principles and practice in second language acquisition. New York: Pergamon.

Laufer, B. (1997). The Lexical plight in second Language reading: Words you know, words you don't know, and words you can't guess. In Coady \& Hucken (Eds.), Second language vocabulary acquisition (pp. 35-54). Cambridge: Cambridge University Press.

Laufer, B., \& Hulistijn. (2001). Incidental vocabulary Acquisition in A Second Language: The Construct of Task Induced Involvement. Applied Linguistics, 22(1),1-26. https://doi.org/10.1093/applin/22.1.1

Maneshi, N. (2017). Incidental Vocabulary Learning through Listening to Songs. Electronic Thesis and Dissertation Repository, 4783. Retrieved from http://ir.lib.uwo.ca/etd/4783.

Meara, P. (1996). The vocabulary knowledge framework. Vocabulary acquisition Research Group Virtual Library.

Migdadi, H. F., Yunus, K., \& Daradkeh, A. A. (2019). The Relationships Between EFL Saudi University Students' Vocabulary and Listening Comprehension. International Journal of Humanities, Philosophy and Language, 2(5), 51-64.

Mohsen, M. A. (2016). Effects of help options in a multimedia listening environment on L2 vocabulary acquisition. Computer Assisted Language Learning, 29(7), 1220-1237. https://doi.org/10.1080/09588221.2016.1210645

Mohsen, M., \& Mahdi, H. (2019). Partial versus full captioning mode to aid L2 vocabulary acquisition: words pronunciation mode. Submitted to a journal.

Mohsen, M., \& Medawis, S. (2019). Second language vocabulary gains from listening versus reading comprehension input: a comparative study. Submitted to a journal.

Musa, N., \& Fojkar, M. (2019). Correlation between Students' English Listening Skills, Vocabulary Skills and out-of-school Listening Exposure. The New Educational Review, 55(1), 42-53. https://doi.org/10.15804/tner.2019.55.1.03

Nation, P. (2000). Learning Vocabulary in Another Language. Cambridge: Cambridge university press.

Nikolova, O. (2004). Effects of visible and invisible hyperlinks on vocabulary acquisition and reading comprehension for high - and average - foreign language achievers. Apprentissage des langues et syste 'mes d'information et de communication, 7, 29-53. https://doi.org/10.4000/alsic.2279

Qian, D. (1999). Assessing the roles of depth and breadth of vocabulary knowledge in reading comprehension. Canadian Modern Language Review, 56(2), 282-308. https://doi.org/10.3138/cmlr.56.2.282

Read, J. (1993). The development of a new measure of L2 vocabulary knowledge. Language Testing, 10(3), 355-371. https://doi.org/10.1177/026553229301000308

Read, J. (1998). Validating a test to measure depth of vocabulary knowledge. In A. Kunnan (Ed.), Validation in language assessment (pp. 41-60). Mahwah, NJ: Lawrence Erlbaum.

Read, J. (2000). Assessing Vocabulary. Cambridge: Cambridge University Press. https://doi.org/10.1017/CBO9780511732942

Rumelhart, D. (1980) Schemata: The Building Blocks of Cognition. In R. Spiro, B. Bruce \& W. Brewer (Eds.), Theoretical Issues in Reading Comprehension, Erlbaum Associates, Mahway (pp. 33-58). https://doi.org/10.4324/9781315107493-4

Schmitt, N., Schmitt, D., \& Clapham, C. (2001). Developing and exploring the behavior of two versions of the vocabulary levels test. Language Testing, 18(1), 55-88. https://doi.org/10.1177/026553220101800103

Stæhr, L. S. (2009) Vocabulary knowledge and advanced listening comprehension in English as a foreign language. Studies in Second Language Acquisition, 31(4), 577-607. https://doi.org/10.1017/S0272263109990039

Suggate, S. P., Lenhard, W., Neudecker, E., \& Schneider, W. (2013). Incidental vocabulary acquisition from stories: Second and fourth graders learn more from listening than reading. First Language, 33(6), 551-571. https://doi.org/10.1177/0142723713503144

Teng, F. (2018). Incidental vocabulary acquisition from reading-only and reading-while-listening: a multi-dimensional approach. Innovation in Language Learning and Teaching, 12(3), 274-288. https://doi.org/10.1080/17501229.2016.1203328

Tragant, M. E., Llanes, B. À., \& Pinyana, G. À. (2018). Linguistic and non-linguistic outcomes of a 
reading-while-listening program for young learners of English. Reading and Writing. https://doi.org/10.1007/s11145-018-9886-x

Valentini, V., Ricketts, J., Py, R., \& Houston-Price, C. (2018). Listening while reading promotes word learning from stories. Journal of Experimental Child Psychology, 167, 10-31 https://doi.org/10.1016/j.jecp.2017.09.022

Van Zeeland, H., \& Schmitt, N. (2013). Lexical coverage in L1 and L2 listening comprehension: The same or different from reading comprehension? Applied Linguistics, 34(4), 457-479. https://doi.org/10.1093/applin/ams074

Vandergrift, L. (2007) Recent developments in second and foreign language listening comprehension research. Language Teaching, 40(3), 191-210. https://doi.org/10.1017/S0261444807004338

Vidal, K. (2011). A Comparison of the Effects of Reading and Listening on Incidental Vocabulary Acquisition. Language Learning, 61(1), 219-258. https://doi.org/10.1111/j.1467-9922.2010.00593.x

Wesche, M., \& Paribakht, T. S. (1996). Assessing Second Language Vocabulary Knowledge: Depth versus Breadth. Canadian Modern Language Review, 53(1), 13-40. https://doi.org/10.3138/cmlr.53.1.13

Wilkins, D. A. (1972). Linguistics in Language Teaching. Cambridge: MFT Press.

Xiaoning, C., \& Feng, T. (2017). assessing the effects of word exposure frequency on incidental vocabulary acquisition from reading and listening. Chinese Journal of Applied Linguistics, 40(1), 56-73. https://doi.org/10.1515/cjal-2017-0004

Zimmerman, C. (1997) Historical trends in second language vocabulary instruction. In J. Coady \& T. Huckin (Eds.), Second language vocabulary acquisition (pp. 5-19). Cambridge: Cambridge University Press. https://doi.org/10.1017/CBO9781139524643.003

\section{Copyrights}

Copyright for this article is retained by the author, with first publication rights granted to the journal.

This is an open-access article distributed under the terms and conditions of the Creative Commons Attribution license (http://creativecommons.org/licenses/by/4.0/). 